\title{
South East Europe and the New Turkish Strategic Vision
}

\author{
Urtak Hamiti, PhD Cand. \\ University of Tirana, Professor at lliria College \\ urtaku@gmail.com
}

Doi:10.5901/ajis.2015.v4n1s2p265

\section{Abstract}

There is turmoil in Turkey, both internally involving Turkish President Recep Taip Erdogan, an undisputed political leader in the past decade in Turkey on one side, and followers of Fetullah Gulen, a prominent and influential religious and political leader currently residing in the Unitest States of America on the other side are fighting fiercely both in courts both in winning public opinion. Dispute is over the future that Turkey should take: towards West and its values or towards its former Ottoman glory projected in new 21 century. The secular order of the Turkish state has been challenged in the recent years as Erdogan promoted its agenda of revitalizing and reaffirming the Turkish Islamic tradition. This was pushed forward with the influence of current Prime Minister Ahmet Davutogllu, who has never hidden his vision of Turkey with a neo-Ottoman future going further to promoting Pan-Islamism under Turkish leadership. There have been numerous allegations that the Government of Turkey is disrupting the work of the opposition as well as preventing freedom of press. In December of 2014, 23 journalists and editors were detained in orchestrated raids accused of having close ties with Fetullah Gulen whom Erdogan accuses of establishing a "parallel organization inside Turkey" aiming to overthrow his democratic government. There is also well known "Ergenekon Affair" which lead to 275 arrests of prominent police and army officers, most highly ranked being Chief General Staff Gen. Iker Basburg. After a five year trial Basburg alongside 18 fellow officers received life-sentences by Istanbul's 13 High Criminal Court.

Keywords: Turkish Strategic Vision and South East Europe, cooperation of Turkey with countries such as Kosovo, Serbia, Bosnia and Herzegovina, Turkish "Strategic Depth" project, effects of neo-Ottomanism in South East

Turkey faces turmoil in the foreign policy as well. From its starting position, crafted by Davutogllu, of Turkey without problems with neighbors, it has now facing unstable relations with Israel, Syria, Egypt, and lastly very dangerous Islamic State. Turkey openly backs Palestinian cause, backed regime change in Syria, backed "Muslim Brotherhood" in Egypt, and currently is in what is described as ambivalent stance with the Islamic State.

Turkish ambitions where adopted in the document "Turkish Strategic Vision 2023", adopted by ruling AK party in September $30^{\text {th }}$ 2012, where a plan was outlined with specific target goals to be met both domestically and more important in foreign policy. According to this Vision Turkey should be placed among decision making countries of the World due to its geopolitical position, military strength while pursuing a new global vision in partnership with political actors that pursue a positive political agenda in a area influenced by Turkey as well as elsewhere in the world.

In this Strategic Document it is mentioned that Turkey places a lot of its efforts in foreign policy with 202 active diplomatic missions throughout the world and aiming to strengthen its ties and influence in the Balkans, Caucasia, Middle East, and Central Asia. Through this Strategic Document, Turkey aims at achieving its dominance role by "zero problems with neighbors", "security for everyone", "economic integration", "multiculturalism and peaceful co-existence with everyone".

Radical change in Turkey's stance towards its past and future has also reinforced the religious factor in its course to promoting neo-Ottomanism. This change has of course affected Balkans, or South East Europe that has for more than five centuries been under direct Turkish rule.

However, South East Europe countries such as Kosovo, Serbia, Macedonia, Montenegro, Bosnia and Hercegovina, Croatia, have reacted differently to Turkish economic and political push to this region. Balkans is a very small region with rigid differences therefore Turkish approach and results have been different so far.

Changes in Turkish foreign and domestic policies and in its regional and international relations in the first and second decade of 21 century stand up in sharp contrast with that of immediate past. After World War II on three separate occasions, Turkey came to brink of war with its neighbors: Armenia in 1992, Greece in 1996, and Syria in 1998, also it took part in supporting NATO operations in Bosnia and Herzegovina in 1995 and Kosovo in 1999. There have been regular military incursions launched in northern Iraq, and continuous tactical military provocations between Greek and 
Turkish air forces, although both are members of NATO. Internally, Turkey was targeted by various human rights associations for violation of human rights of Kurdish minority as well as political opposition. Today, the contrast with current situation is striking, as over the last decade Turkey has sought and achieved rapprochement with Greece, Syria, Iraq, Armenia, Iran and Russia. Turkey has adopted an active foreign policy that had a sizable impact in domestic policy as well since it had proclaimed the "zero problems" with its neighbors policy. This policy was aimed at improving bilateral and regional cooperation in the Balkans and with some former member countries of Soviet Union, and gradually has been expanded to the Middle East, the Gulf countries, and the countries of North Africa as well. Accounting for these developments on the domestic and international level is critical in order to understand Turkey's foreign policy orientation, marked by "zero problems" and elaborated in "Strategic Depth" by current Turkish Prime Minister Ahmet Davutoglu.

Strategic Depth seeks to reposition Turkey from the outskirts of international relations to the center as an actor sitting at the intersection of multiple regions. Turkey today is courting new alliances in order to maintain optimal regional and global independence and influence ${ }^{1}$ by specifically taking on a larger role in its former Ottoman territories through "dialogue and cooperation" over "coercion and confrontation". This approach has been hailed businessman and civil society which have been eager to develop and foster closer ties with neighbors and other countries in developing economic and social cooperation. In other words, the doctrine of "Strategic Depth", that is still followed by Turkey, provided a base to develop deeper and stronger ties to ist neighbors. It also conceptualizes a foreign policy trend which has been in the making since the days of former Prime Minister and President Turgut Ozal (late 80s beginning of 90s) as well as former Foreign Minister Ismail Cem (late 90s) ${ }^{2}$.

Davutoglu's proclaimed Grand Strategy in its core emphasizes Turkey's location in geopolitical areas of influence, with a foothold in Europe and Asia, in control of Bosporus, and with a long historical legacy of Ottoman Empire. ${ }^{3}$ Davutoglu emphasizes Turkey's connections to the Balkans, the Middle East, Central Asia. He argues that Turkey is the natural heir to the Ottoman Empire and aims to give Turkey the role it had before in unifying the Muslim world also emphasizing that Turkey cannot be a peripheral force of NATO, EU or Asia. Davutoglu contends that Turkey is geographically positioned as a central international player "a country with a close land basin, the epicenter of the Balkans, the Middle East and the Caucasus, the center of Eurasia with a land belt that crosses the Mediterranean and the Pacific. Such a geostrategic vision reflects the newly acquired self-confidence on the part of newly empowered Turkish leadership who are supportive of a more proactive foreign policy-particulary in what they call "the Ottoman geopolitical space"

The catalyst for change was the emergence of the Justice and Development Party (AKP) in 2002 as the main political force which drove changes to Turkeys foreign policy. AKP articulated a vision for improvement of relations with all of Turkey's neighbors privileging Muslim space in the Middle East, such as Lebanon, Iran, Iraq and Syria, and stretching further to the Balkans and Caucuses. Central to this revival of Ottoman legacies has been expandind economic interests and regional dynamism represented by the rise of new rural Anatolian businesses which emerged as strong advocates for further Turkish expansion into Middle Eastern rather than European markets. Together with more Anatolian influence came a more conservative outlook based in Turkey's Muslim heritage.

In a country that has experienced four military coups (one being the "soft" coup that resulted in closure of the Refah Party) $)^{4}$, and also one called the "electronic coup" in 2007 aimed at discrediting the AKP, the emergence of AKP was seen as the voice of the largest numbers of Turkish people which demanded internal changes and those in the international level.

The change in Turkish foreign policy hinges on Turkey's internal transformation and democratization, was started, inter-alia, by its EU accession process, and propelled by the rise of ruling AKP under the leadership of former Prime Minister and current President Recep Tayip Erdogan. It is a known fact that Turkish foreign policy has always been a concern of the military and elites of the Ministry of Foreign Affairs. In the past decade these institutions have been transformed and other state bodies have acquired a role in foreign policy making.

The democratization of Turkey has made the government more accountable and aware of the public opinion more than other governments of the past. The upshot and, for some observers, the irony of the increasingly democratic Turkey is a growing readiness to diverge and oppose US and EU when their policies are perceived as countering those of Turkey

\footnotetext{
${ }^{1}$ For further information on this doctrine see Joshua Walker, "Learning Strategic Depth: Implications of Turkey's new foreign policy doctrine", Insight Turkey, Vol. 9, No. 3, (2007), 32-47

2 Meliha Altunsik-Benli, "Worldviews and Turkish Foreign Policy in the Middle East", New Perspectives on Turkey, No.40 (2009), 171-194 ${ }^{3}$ Ahmet Davutoglu, "Strtegik Derinlik, Turkiye'nin Uluslararasi Konumu", (Istannbul: Kure Yayinlari, 2001), (Strategic Depth, Turkey's International Position)

${ }^{4}$ Refah Party or the Welfare Party was an Islamist Political Party that emerged in 1983 and is considered a predecessor of today's AKP 
and Turkish people. Turkish generals and diplomats tend to support only policies that are of benefit to Turkish people since they are held accountable for their foreign policy decisions more than ever in Turkey's modern history. For some internal observers, Turkey's new self-awareness as a regional power means that rather than simply being able to rely on Turkey as an instrument of Western power projection in the Middle East, the West now faces a stronger and more assertive Turkey that can and will disagree, from time to time, on key foreign policy issues and a Turkey that aims to spread its influence in all directions especially in areas it had governed during Ottoman Empire.

One of important areas for Turkey and its growing influence is the Balkans. The name Balkans itself originates from Turkish language meaning "a chain of mountains filled with forests". Balkans is in fact South Eastern Europe as this name is more present currently since Europeans were trying to avoid usage of the name Balkans because of its connotation to violence and wars.

Turkey calls itself a "Balkan country" historically, geographically, and culturally, that is why this region is very important for Turkey. ${ }^{5}$ Turkey considers that after the withdrawal of the Ottoman Empire in the 19 century around 7 million Turks have migrated from the Balkans to Turkey. The importance of Balkans also is in the fact that is considered to the "gate to Europe" for Turkey land wise. The new Turkish foreign policy and the old Turkish foreign policy had Balkans and the newly created countries following the break-up of Yugoslavia (1991) in its very important outlook.

In New Turkish Foreign Policy the aim of membership in the EU remains an orientation goal, but now it is in conjunction with newly created reality in South Eastern Europe. This Policy was created by various experts that have taken into account the important of security but also internal desecuritization or easing relations with neighbors as well as easing religious factor within Turkey. Turkish experts relied also on Michael William's theory that securitization is a process of accumulated power in which various actors participate according to their capacity differently, but with the aim of responding efficiently in times of jeopardy. ${ }^{6}$

The distinction of Old and New Turkish Foreign Policy toward South East Europe is not only minimal, formal, or linguistic. The distinction is seen before and after the year 2000. Before the year of 2000, Turkey was engaged in NATO operations involving Bosnia and Herzegovina and Kosovo. It can be said that Turkey's efforts up to the war in Kosovo 1998-1999 were directed toward calming down the situation in Former Yugoslavia. But, when bombing of Yugoslavia started Turkey changed its policy and was fully engaged in the bombing campaign. Turkish President Syleiman Demirel stated at the time "Kosovars are our brothers and heritage of our history"7 adding that "it is our duty to save our Kosovar brothers"8.

The conflict in Kosovo can be seen as a force that created a turn in Turkish foreign policy toward New Turkish Foreign Policy and it had also intensified Islamist movements in Turkey. This movement alongside other various factors represents that fundament of current and future Turkish internal and foreign policy with a reference that the Islamist movement in Turkey is tolerant and poses no threat to other non-Muslim religions since it has plenty of historical coexistence with other religions in Europe and South East Europe in particular. For Turkey, the issue of Kosovo is settled. Turkey was one of the first countries to recognize Kosovo, although it continues to nurture good relations with Serbia.

This is in fact the aim of "Strategic Depth" doctrine as Davutoglu stated announcing that the possibility of renewal of Ottoman Empire in some form is possible. "We would like new Balkans that is based in political values, economic independence, cooperation and cultural harmony. This is similar to Ottoman Balkans. We want to revive such a region in Balkans...Ottoman centuries were a successful story and should be revived" (Davutoglu statement).

John Feffer, from Institute for Policy Studies, expands further the meaning of "Strategic Depth" in his articles "Pax Ottomanica" and "Stealth Superpower". Among others he states: "Today, a dynamic neo-Ottoman spirit moves Turkey. Before, Turkey was firmly secular, but now it has started applying Islamic democracy. Before, Turkey was under control of the Army, but now it is in the process of reducing the power of the Army through legal norms....Most critical is the introduction of the New Foreign Policy. Turkey is dropping its half a century role of following the US no matter what and is creating its own relations and geopolitical role"s.

Toward South East Europe Turkey applies a different policy from, for example Middle East. Turkey considers this

\footnotetext{
${ }^{5}$ Declaration, $2^{\text {nd }}$ International Balkan Congress "Socioeconomic Cooperation and Development in the Balkans", April 24-26 2009, internet http://www.tasam.org/Final 18.03.2015

${ }^{6}$ Michael Williams, "Words, Images, Enemies-Securitization and International Politics", U: International Studies Quarterly 47 (4), 2003, 511-531

${ }^{7}$ Milliyet, 7.04.1999; Aksam 08.04.1999

${ }^{8}$ Anadolu Ajanci, 04.04.1999

${ }_{99}$ John Fefer, Institute for Policy Studies, London, internet: http://original.antiwar.com/engelhard/2010/06/13/pax-ottomanica/ 14.03.2014 
region to be very fragile and an area in which Turkey can bring stability through its influence and through using proEuropean values such as promotion of human rights and democracy. Main countries of interest for Turkey in this area are Bosnia and Herzegovina and Serbia because of their past and actual needs of these countries that, according to Turkey, demand Turkish influence in keeping the situation calm and bringing more democracy. "Sarajevo is Ottoman heritage in miniature. If you don't' understand Sarajevo than you don't understand Ottoman Empire. Sarajevo is the prototype of Ottoman civilization. Sarajevo is the prototype of the rising if Balkans", sums up Davutoglu. ${ }^{10}$ Davutoglu has stated also that "There are more Bosnians and Albanians living in Turkey than in Bosnia and Albania"11

By recalling a period of domination, tradition, cultural heritage, and in principal historical depth, Turkey is in some ways laying its claim over South East Europe. Turkey officially still wants to be part of EU alongside other Balkan countries that are not yet included into EU. At the same time Turkey is offering to the countries of the region a new perspective of a new central geopolitical and geoeconomic constellation rather than periphery of Europe. Whether it would be more beneficial for countries of South East Europe to be central through Turkish Strategic Vision in comparison to peripheral role through EU it cannot be concluded without more in depth analysis.

It can be said though that through its influence in countries of South East Europe, political support and economic investments, Turkey is actually striving for a larger domain that is based in three main components:

- process of desecurisation and promotion of security in Turkey shows that a lot is based on the Islamic factor within the country

- $\quad$ second component or second pier is cultural-historical heritage and experience that, according to Turkish point of view, makes Turkey competent for cultural integration of countries and nations formerly part of Ottoman Empire

Third component is the economic-geopolitical position, potential and space that allows Turkey to link three continents: Europe, Asia, and Africa.

The third component has so far shown openly the idea of New Turkish Foreign Policy based on New Strategic Vision. It is obvious that Turkey does not see itself as the periphery of Europe, but rather than that an inter-continental center of Euro-Asia and Africa, plus the largest link of oil and natural gas. In the context of its own perspective Turkey takes into account and is even offering to countries of South East Europe a position in the center of developments.

Finally, we are currently witnessing a difficult period for Turkey and its leaders. Internally, President Erdogan is at odds with influential Fetullah Gulen, internationally Turkey has to mend relations with Syria, Israel and Egypt. President Erdogan though is not moving from "Strategic Depth" practices. Proof of that is his recent visit to Teheran, Iran immediately after US and allies have reached the agreement on Iran's nuclear program. Also, Erdogan has supported the latest initiative of Saudi Arabia to put an end to bloodshed in Yemen. Based on previous experience it is easily possible that Turkish leaders will take further pragmatic steps and will be again a factor of political stability supported by economic support or cooperation with the countries of the Middle East. As for South East Europe, Turkey's influence is solid and unshaken.

10 Daily News Montenegro 29.09.2009, 2

11 Daily News Montenegro, 29.10.2009, 4 